\title{
A nutrition and conditioning intervention for natural bodybuilding contest preparation: observations and suggestions

\author{
Paulo Gentil
}

\begin{abstract}
Bodybuilding is full of myths and practices that are contrary to the scientific literature, which can lead to health problems. Adopting a scientifically designed approach is very important, as it may help bodybuilders to achieve better results while preserving their health. However, I have some criticism regarding some practices adopted in the referred article as ad libitum ingestion of sugar-free cordial and flavored tea and the performance of the exercise in fasted state, as it seems to bring no benefit and have some potential problems. Some suggestion are made in order to preserve FFM, like changing training split and exercise selection; increasing carbohydrate ingestion and decreasing protein intake; changing the resistance training stimuli and reducing the volume of aerobic exercises and increase its intensity.
\end{abstract}

Keywords: Bodybuilder, Resistance training, High intensity interval training, Protein ingestion, Carbohydrate ingestion

I would like to congratulate the authors for the interesting case study [1]. Bodybuilding is full of myths and practices that are contrary to the scientific literature, which can lead to health problems, as previously reported in this journal [2]. Adopting a scientifically designed approach is very important, as it may help bodybuilders to achieve better results while preserving their health.

However, I have some criticism regarding the adopted ad libitum ingestion of sugar-free cordial and flavored tea. Although sweeteners may be valuable in substitution to sugar or high caloric foods [3], some large scale prospective cohort studies found positive correlation between artificial sweetener ingestion and weight gain $[4,5]$. There is a suggestion that artificial sweeteners do not activate the food reward pathways and may encourage sugar dependence [5], which may be deleterious to diet adherence in long term. Moreover, the regular use of sweetener has been linked to glucose intolerance, as suggested by recent reviews [6, 7]. So, it is recommended to employ a systematic reduction of sugar ingestion, without any substitution for sweeteners [5].

Correspondence: paulogentil@hotmail.com

College of Physical Education and Dance, Federal University of Goias,

Avenida Esperança s/n, Campus Samambaia, Goiania 74.690-900, GO, Brazil
Another questionable practice is the performance of the exercise in fasted state, as it brings no benefit in terms of fat loss [8] and can negatively impact energy expenditure and fat metabolism [9]. So, it is advisable to progressively change this habit.

That said, I would like to make some observations and suggestions. The 2014 Olympia Men's Physique champion was $173 \mathrm{~cm}$ with $88 \mathrm{~kg}$ during off season and $75 \mathrm{~kg}$ during contest. It results in a BMI of 30 and 25 , respectively. The participant of the study had a BMI of 27 and dropped to 23 after the preparation. It seems prudent to adopt strategies to preserve FFM loss, since he is probably undersized for competing at high level.

It is important to note that the volume of training used in this study is considerably high and previous studies suggested that it might be necessary to reduce resistance training volume during caloric restriction [10]. One first thought is to change training split and exercise selection to avoid excessive stress. Previous studies suggest that multi joint exercises promote sufficient stimuli for gaining muscle size and strength in all muscles involved in the exercise [11] and there seems to be no additional benefit in performing single joint exercises $[12,13]$. Therefore the use of separate sessions to train 
the arms does not seem to be necessary and may lead to an unbalance between stress and recovery.

The proposed diet decreased carbohydrate ingestion to $23-25 \%$ of the calories ingested and established protein intake at approximately $2.4 \mathrm{~g}$ per $\mathrm{kg}$ of body weight. Although the benefits of high protein diets on weight loss are highlighted [14], the results of meta-analyses indicate that the quantity of protein necessary to promote weight management and preserve lean mass lies somewhere between 1.2 and $1.6 \mathrm{~g} / \mathrm{kg}$ [15-17]. The highest suggestion of protein ingestion was published by Phillips \& Van Loon [18], who recommended to increase protein intake to 1.8 to $2.7 \mathrm{~g} / \mathrm{kg}$ in order to optimize the ratio of fat-to-lean tissue mass loss during hypoenergetic periods. However, the authors showed no convincing evidence for proposing this number.

Additionally, a systematic review by Helms et al. [19] suggested that $2.3-3.1 \mathrm{~g} / \mathrm{kg}$ FFM to be appropriate for lean, resistance-trained athletes in hypoenergetic conditions. However it is important to note that, among the studies used by Helms et al, only two used protein intakes over $2 \mathrm{~g} / \mathrm{kg}[20,21]$ and, among them, only one compared the effects of different protein intakes [21]. In this study, by Mettler et al. [21], the low protein group ingested only $1 \mathrm{~g} / \mathrm{kg}$ of protein, which is very low. Therefore, although increasing protein intake may be a valuable to strategy as suggested by recent studies [22], it is important for coaches and dietitians to know that there are other nutritional strategies that can be used during precontest, especially if their athletes do not tolerate severe restrictions in carbohydrate or fat. It is important to note that the literature recommends the ingestion of 1.2 to $2 \mathrm{~g}$ of protein per $\mathrm{kg}$ of body weight for strength athletes [23-25] and there are some suggestions of no benefit on increasing it above this level [26].

As low carbohydrate ingestion may compromise exercise performance [18], one suggestion would be to increase carbohydrate ingestion and decrease protein intake. Another suggestion is to change the resistance training stimuli. Although it is commonly suggested that the optimal resistance training protocol for promoting fat loss should be done with high volume and high repetitions, there is evidence that low volume and high intensity workouts may promote more favorable acute [27] and chronic outcomes [28, 29] for those wanting to lose fat. Moreover, if one is to adopt low carbohydrate diets, using low repetition and high load resistance training protocols may be advantageous, since this type of training rely less on the glycolitic system [30].

Finally, it would be recommended to reduce the volume of aerobic exercises and increase its intensity, since it has been shown that the higher the volume of aerobic exercise, the lower the muscle hypertrophy [31], in this regard it is important to note that running may have a more negative effect than cycling [32]. On the other hand, the higher the exercise intensity, the higher the fat loss [31] and it seems that the effect of regular aerobic exercise on body fat is negligible [32]. Taken together, this make high intensity interval training more recommended than long duration and low intensity training for both losing fat and preserving fat free mass.

\section{Competing interests}

The authors declare that they have no competing interests.

\section{Author's contribution}

PG conceived and drafted the manuscript.

\section{Author's information}

PG - PhD in Health Sciences. Professor of the Department of Physical Education and Dance at the Federal University of Goias, Brazil. Associate Researcher at University of Brasilia, Brazil.

Received: 19 May 2015 Accepted: 17 December 2015

Published online: 21 December 2015

\section{References}

1. Robinson SL, Lambeth-Mansell A, Gillibrand G, Smith-Ryan A, and Bannock L. A nutrition and conditioning intervention for natural bodybuilding contest preparation: Case study. J Int Soc Sports Nutr. 2015;12:20.

2. Della Guardia L, Cavallaro M, Cena H. The risks of self-made diets: The case of an amateur bodybuilder. J Int Soc Sports Nutr. 2015;12:16.

3. Miller PE, Perez V. Low-calorie sweeteners and body weight and composition: A meta-analysis of randomized controlled trials and prospective cohort studies. Am J Clin Nutr. 2014;100:765-77.

4. Fowler SP, Williams K, Resendez RG, Hunt KJ, Hazuda HP, Stern MP, et al. Fueling the obesity epidemic? Artificially sweetened beverage use and long-term weight gain. Obesity (Silver Spring). 2008;16:1894-900.

5. Yang Q. Gain weight by "going diet?" Artificial sweeteners and the neurobiology of sugar cravings: Neuroscience 2010. Yale J Biol Med. 2010;83:101-8.

6. Suez J, Korem T, Zeevi D, Zilberman-Schapira G, Thaiss CA, Maza O, et al. Artificial sweeteners induce glucose intolerance by altering the gut microbiota. Nature. 2014:514:181-6.

7. Pepino MY. Metabolic effects of non-nutritive sweeteners. Physiol Behav. 2015;152(Pt B):450-5.

8. Schoenfeld BJ, Aragon AA, Wilborn CD, Krieger JW, and Sonmez GT. Body composition changes associated with fasted versus non-fasted aerobic exercise. JISSN. 2014;11:54.

9. Paoli A, Marcolin G, Zonin F, Neri M, Sivieri A, Pacelli QF, et al. Exercising fasting or fed to enhance fat loss? Influence of food intake on respiratory ratio and excess postexercise oxygen consumption after a bout of endurance training. Int J Sport Nutr Exerc Metab. 2011;21:48-54.

10. Rebai H, Chtourou H, Zarrouk N, Harzallah A, Kanoun I, Dogui M, et al. Reducing resistance training volume during ramadan improves muscle strength and power in football players. Int J Sports Med. 2014;35:432-7.

11. Gentil P, Soares SR, Bottaro M. Single vs multi-joint resistance exercises: Effects on muscle strength and hypertrophy. Asian J Sports Med. 2015;6:e24057.

12. Gentil P, Soares SR, Pereira MC, da Cunha RR, Martorelli SS, Martorelli AS, et al. Effect of adding single-joint exercises to a multi-joint exercise resistance-training program on strength and hypertrophy in untrained subjects. Appl Physiol Nutr Metab. 2013;38:341-4.

13. França HS, Branco PAN, Guedes Jr DP, Gentil P, Steele J, Teixeira CV, et al. The effects of adding single-joint exercises to a multi-joint exercise resistance training program on upper body muscle strength and size in trained men. Appl Physiol Nutr Metab. 2015;40(8):822-6.

14. Leidy HJ, Clifton PM, Astrup A, Wycherley TP, Westerterp-Plantenga MS, Luscombe-Marsh ND, et al. The role of protein in weight loss and maintenance. Am J Clin Nutr. 2015.

15. Leidy HJ, Carnell NS, Mattes RD, and Campbell WW. Higher protein intake preserves lean mass and satiety with weight loss in pre-obese and obese women. Obesity (Silver Spring). 2007;15:421-9. 
16. Soenen S, Martens EA, Hochstenbach-Waelen A, Lemmens SG, and Westerterp-Plantenga MS. Normal protein intake is required for body weight loss and weight maintenance, and elevated protein intake for additional preservation of resting energy expenditure and fat free mass. J Nutr. 2013;143:591-6.

17. Layman DK, Evans E, Baum Jl, Seyler J, Erickson DJ, Boileau RA, et al. Dietary protein and exercise have additive effects on body composition during weight loss in adult women. J Nutr. 2005;135:1903-10.

18. Phillips SM, Van Loon LJ. Dietary protein for athletes: From requirements to optimum adaptation. J Sports Sci. 2011;29 Suppl 1:S29-38.

19. Helms ER, Zinn C, Rowlands DS, and Brown SR. A systematic review of dietary protein during caloric restriction in resistance trained lean athletes: A case for higher intakes. Int J Sport Nutr Exerc Metab. 2014;24:127-38.

20. Maestu J, Eliakim A, Jurimae J, Valter I, and Jurimae T. Anabolic and catabolic hormones and energy balance of the male bodybuilders during the preparation for the competition. J Strength Cond Res. 2010;24:1074-81.

21. Mettler S, Mitchell N, Tipton KD. Increased protein intake reduces lean body mass loss during weight loss in athletes. Med Sci Sports Exerc. 2010;42:326-37.

22. Antonio J, Ellerbroek A, Silver T, Orris S, Scheiner M, Gonzalez A, et al. A high protein diet $(3.4 \mathrm{~g} / \mathrm{kg} / \mathrm{d})$ combined with a heavy resistance training program improves body composition in healthy trained men and women-a follow-up investigation. J Int Soc Sports Nutr. 2015;12:39.

23. Lemon PW, Tarnopolsky MA, MacDougall JD, and Atkinson SA. Protein requirements and muscle mass/strength changes during intensive training in novice bodybuilders. J Appl Physiol. 1992;73:767-75.

24. Lemon PW. Protein and amino acid needs of the strength athlete. Int J Sport Nutr. 1991;1:127-45.

25. Campbell B, Kreider RB, Ziegenfuss T, La Bounty P, Roberts M, Burke D, et al. International society of sports nutrition position stand: Protein and exercise. J Int Soc Sports Nutr. 2007;4:8.

26. Antonio J, Peacock CA, Ellerbroek A, Fromhoff B, and Silver T. The effects of consuming a high protein diet $(4.4 \mathrm{~g} / \mathrm{kg} / \mathrm{d})$ on body composition in resistance-trained individuals. J Int Soc Sports Nutr. 2014;11:19.

27. Paoli A, Moro T, Marcolin G, Neri M, Bianco A, Palma A, et al. High-intensity interval resistance training (hirt) influences resting energy expenditure and respiratory ratio in non-dieting individuals. J Transl Med. 2012;10:237.

28. Paoli A, Pacelli F, Bargossi AM, Marcolin G, Guzzinati S, Neri M, et al. Effects of three distinct protocols of fitness training on body composition, strength and blood lactate. J Sports Med Phys Fitness. 2010;50:43-51.

29. Paoli A, Pacelli QF, Moro T, Marcolin G, Neri M, Battaglia G, et al. Effects of high-intensity circuit training, low-intensity circuit training and endurance training on blood pressure and lipoproteins in middle-aged overweight men. Lipids Health Dis. 2013;12:131.

30. Kraemer WJ, Marchitelli L, Gordon SE, Harman E, Dziados JE, Mello R, et al. Hormonal and growth factor responses to heavy resistance exercise protocols. J Appl Physiol. 1990;69:1442-50.

31. Wilson JM, Loenneke JP, Jo E, Wilson GJ, Zourdos MC, Kim JS, et al. The effects of endurance, strength, and power training on muscle fiber type shifting. J Strength Cond Res. 2012;26:1724-9.

32. Boutcher SH. High-intensity intermittent exercise and fat loss. J Obes. 2011;2011:868305

\section{Submit your next manuscript to BioMed Central and we will help you at every step:}

- We accept pre-submission inquiries

- Our selector tool helps you to find the most relevant journal

- We provide round the clock customer support

- Convenient online submission

- Thorough peer review

- Inclusion in PubMed and all major indexing services

- Maximum visibility for your research

Submit your manuscript at www.biomedcentral.com/submit

) Biomed Central 